Department of Physiology and Pharmacology, Federal University of Ceará, Fortaleza, Ceará, Brazil

Flávia A. Santos, Regilane M. Silva, Adriana R. Tomé, Vietla S. N. Rao

Department of Pathology and Legal Medicine, Federal University of Ceará, Fortaleza, Ceará, Brazil

Margarida M. L. Pompeu, Maria J. Teixeira

Pathology and Cellular Biology Laboratory, FIOCRUZ, Rio de Janeiro, RJ, Brazil

Luiz A. R. De Freitas, Valderes L. De Souza

Correspondence: V. S. N. Rao, Departamento de Fisiologia e Farmacologia, Faculdade de Medicina, Rua Cel. Nunes de Melo, 1127, Caixa Postal 3157, Porangabussu, 60430-270 Fortaleza, CE, Brasil.

Funding: This work was supported by Conselho Nacional de Desenvolvimento Científico e Tecnológico (CNPq, 300870/98-1).

\section{1,8-Cineole protects against liver failure in an in-vivo murine model of endotoxemic shock}

\author{
Flávia A. Santos, Regilane M. Silva, Adriana R. Tomé, Vietla S. N. Rao, \\ Margarida M. L. Pompeu, Maria J. Teixeira, Luiz A. R. De Freitas and \\ Valderes L. De Souza
}

\section{Abstract}

The effects of 1,8-cineole on D-galactosamine/lipopolysaccharide (GaIN/LPS)-induced shock model of liver injury was investigated in mice. The co-administration of GaIN $\left(700 \mathrm{mg} \mathrm{kg}^{-1}\right.$, i.p.) and LPS ( $5 \mu \mathrm{g} \mathrm{kg}^{-1}$, i.p.) greatly elevated serum concentrations of tumour necrosis factor- $\alpha$ (TNF$\alpha$ ), alanine aminotransferase and aspartate aminotransferase, and induced massive hepatic necrosis and lethality in $100 \%$ of control mice. Pretreatment with 1,8-cineole $\left(400 \mathrm{mg} \mathrm{kg}^{-1}\right.$, p.o.) and dexamethasone ( $1 \mathrm{mg} \mathrm{kg}^{-1}$, s.c.), $60 \mathrm{~min}$ before GalN/LPS, offered complete protection $(100 \%)$ against the lethal shock and acute elevation in serum TNF- $\alpha$ and serum transaminases. Hepatic necrosis induced by GaIN/LPS was also greatly reduced by both 1,8-cineole and dexamethasone treatment. The results indicate that 1,8-cineole protects mice against GaIN/LPSinduced liver injury through the inhibition of TNF- $\alpha$ production, and suggest that 1,8-cineole may be a promising agent to combat septic-shock-associated pathologies.

\section{Introduction}

1,8-cineole (cineole; eucalyptol), a monoterpenoid present in many essential oils of eucalyptus, rosemary and psidium plant species, is traditionally used for the treatment of symptoms of airway diseases exacerbated by infection, and its inhibitory effect on the growth of several microorganisms has recently been reported (Pattnaik et al 1997). It is also used largely by the pharmaceutical industry in various medicaments, as a skin penetration enhancer for topical drugs, and to promote mucociliary clearance in antitussives and expectorants (Williams \& Barry 1991; Laude et al 1994; Levison et al 1994; Gao \& Singh 1998). We previously established the local pro-inflammatory (Santos \& Rao 1997) and systemic antiinflammatory and analgesic effects of 1,8-cineole (Santos \& Rao 2000). Those studies suggested a role for connective tissue mast cells in the pro-inflammatory effects of 1,8-cineole. Recently, an inhibitory effect of 1,8-cineole on lipopolysaccharide (LPS)- and interleukin-1 $\beta$ (IL-1 $\beta$ )-stimulated mediator production of tumour necrosis factor- $\alpha(\mathrm{TNF}-\alpha)$, IL- $1 \beta$, leukotriene $\mathrm{B}_{4}\left(\mathrm{LTB}_{4}\right)$ and thromboxane $\mathrm{B}_{2}\left(\mathrm{TXB}_{2}\right)$ from human blood monocytes has been demonstrated in-vitro (Juergens et al 1998a). Further, a significant inhibition of the production of arachidonic acid metabolites $\mathrm{LTB}_{4}$ and $\mathrm{PGE}_{2}$, measured ex-vivo, from isolated monocytes of bronchial asthma patients treated with 1,8-cineole was observed (Juergens et al 1998b). These findings may, at least in part, explain the systemic anti-inflammatory and 
analgesic effects of 1,8-cineole. This study examined the effects of 1,8-cineole in an in-vivo murine model of septic shock syndrome induced by D-galactosamine/ LPS (GalN/LPS) that is characterized by early apoptosis and subsequent liver cell lysis (Leist et al 1995), and in which the central role of $\mathrm{TNF}-\alpha$ has been firmly established (Tiegs et al 1989; Dinarello 1991; Morikawa et al 1998; Endo et al 1999). The effects of 1,8-cineole in this model were compared with the effects produced by the reference drug dexamethasone.

\section{Materials and Methods}

\section{Animals}

Male Swiss albino mice, 22-25 g, were housed in groups of ten and maintained at $21 \pm 2^{\circ} \mathrm{C}$ with a 12 -h light-dark cycle and allowed free access to food (purina chow) and water. Food was withheld for a period of $12-15 \mathrm{~h}$ before the experiments. Experiments were carried out in accordance with the internationally accepted principles, and the protocols were approved by the Institutional Animal Care and Use Committee of the Federal University of Ceará, Fortaleza.

\section{Chemicals}

Escherichia coli LPS (0111:B4), GalN and 1,8-cineole were purchased from Sigma, St Louis, MO. Dexamethasone was obtained from Merck Sharp \& Dohme, Brazil. The enzyme kits for alanine aminotransferase (ALT) and aspartate aminotransferase (AST) were from Labtest Diagnostics, Brazil.

\section{GaIN/LPS-induced endotoxemic shock}

Endotoxemic shock was induced by GalN (700 $\left.\mathrm{mg} \mathrm{kg}^{-1}\right)$ and LPS $\left(5 \mu \mathrm{g} \mathrm{kg}^{-1}\right)$. These were dissolved in normal saline and co-administered intraperitoneally in a total volume of $500 \mu \mathrm{L}$. 1,8-Cineole $(100,200$, and $400 \mathrm{mg}$ $\mathrm{kg}^{-1}$, p.o.), dexamethasone (1 $\mathrm{mg} \mathrm{kg}^{-1}$, s.c.), or vehicle ( $3 \%$ Tween 80 in distilled water, $10 \mathrm{~mL} \mathrm{~kg}^{-1}$, p.o.) were administered $1 \mathrm{~h}$ before GalN/LPS injection. The percentage survival was evaluated after $24 \mathrm{~h}$.

\section{Determination of serum levels of TNF- $\alpha$, transaminases and hepatic weight}

In a separate set of experiments, mice were pretreated with 1,8-cineole (400 mg kg-1, p.o.), dexamethasone $\left(1 \mathrm{mg} \mathrm{kg}{ }^{-1}\right.$, s.c.) or vehicle $(3 \%$ Tween 80 in normal saline, $10 \mathrm{~mL} \mathrm{~kg}{ }^{-1}$, p.o.), $1 \mathrm{~h}$ before the administration of GalN/LPS. At $4 \mathrm{~h}$ after GalN/LPS administration, blood samples from the retro-orbital plexus were obtained under light ether anaesthesia. The blood was

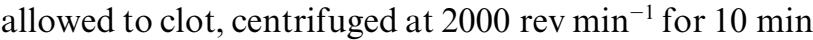
and the serum separated. The activity of serum enzymes, ALT and AST as biochemical indicators of liver function were measured using the RA-50 analyser (Bayer, Brazil) with respective test kits. Serum TNF- $\alpha$ levels were determined using an enzyme-linked immunosorbent assay (ELISA) kit specific for murine TNF- $\alpha$ (PharMingen, San Diego, CA). Each experiment was performed in triplicate. A standard curve was obtained with serial dilutions of murine recombinant TNF- $\alpha$

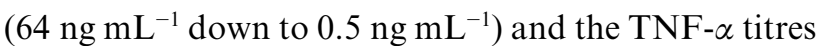

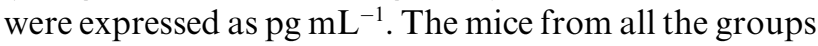
were killed by using an excess of ether, and the entire liver tissue from each mouse was collected and weighed.

\section{Histological analysis of liver damage}

Liver tissue from each mouse was fixed in $10 \%$ neutral formalin and processed for paraffin embedding. Sections $(6 \mu \mathrm{m})$ were prepared and stained with haematoxylin and eosin dye. Histological changes were studied under a light microscope by an independent person unaware of the treatment groups.

\section{Statistical analysis}

Data are expressed as mean \pm s.d. The percentage survival data were analysed by non-parametric analysis of variance (Kruskal-Wallis). Hepatic weight and serum TNF- $\alpha$ concentrations were analysed by analysis of variance followed by Student Newman Keul's test. $P<$ 0.05 was considered to be indicative of significance.

\section{Results}

\section{Effects on survival of mice injected with GalN/LPS}

The percentage survival of mice $24 \mathrm{~h}$ after intraperitoneal injection of GalN/LPS is shown in Figure 1. GalN/LPS caused $100 \%$ lethality in vehicle-treated control mice. Death occurred between 5 and $8 \mathrm{~h}$ after GalN/LPS administration. Pretreatment with 1,8cineole at doses of 200 and $400 \mathrm{mg} \mathrm{kg}^{-1}$, but not at 


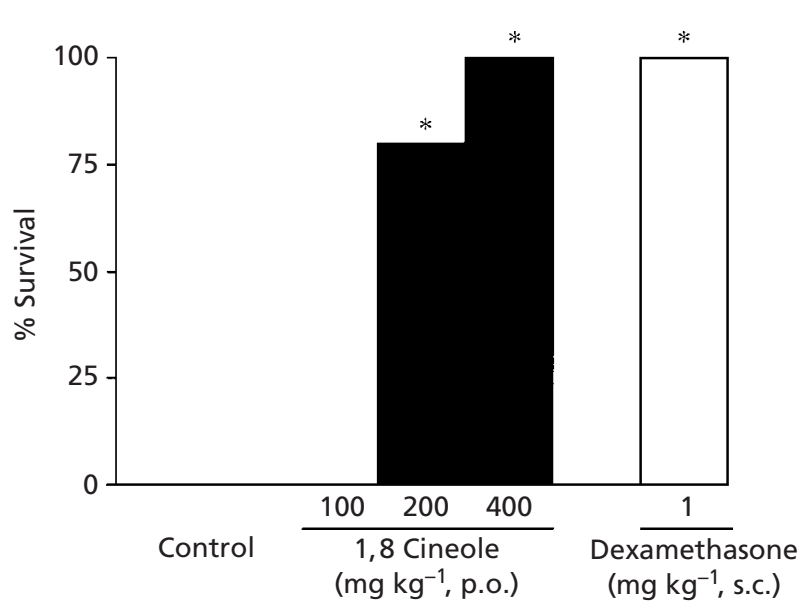

Figure 1 Effects of 1,8-cineole and dexamethasone on D-galactosamine/lipopolysaccharide (GalN/LPS) toxicity in mice. Mice were treated with GalN (700 $\mathrm{mg} \mathrm{kg}^{-1}$, i.p.) and LPS $\left(5 \mu \mathrm{g} \mathrm{kg}^{-1}\right)$ with or without 1,8-cineole or dexamethasone. The test drugs or vehicle (controls, $10 \mathrm{~mL} \mathrm{~kg}^{-1} 3 \%$ Tween 80 in water, p.o.) were administered $1 \mathrm{~h}$ before GalN/LPS and the percentage survival after $24 \mathrm{~h}$ was noted. Data are mean $\pm \mathrm{s} . \mathrm{d}, \mathrm{n}=10 . * P<0.01$ significantly different compared with control.

$100 \mathrm{mg} \mathrm{kg}{ }^{-1}$, significantly inhibited the lethality produced by GalN/LPS, and the survival rate in these groups was 80 and $100 \%$, respectively, compared with $0 \%$ survival observed in control mice. Dexamethasone $\left(1 \mathrm{mg} \mathrm{kg}{ }^{-1}\right)$ also offered complete protection against GalN/LPS-induced mortality.

\section{Effects on serum TNF- $\alpha$, serum enzymes and hepatic weight}

Compared with naive mice, serum samples obtained $4 \mathrm{~h}$ after single intraperitoneal injection of GalN/LPS in vehicle-treated control mice showed markedly elevated (9.27-fold) concentrations of TNF- $\alpha$ (Figure 2A). GalN/LPS-induced increases in serum TNF- $\alpha$ concentrations were significantly less in mice pretreated with 1,8-cineole $\left(400 \mathrm{mg} \mathrm{kg}^{-1}\right)$ or dexamethasone $\left(1 \mathrm{mg} \mathrm{kg}^{-1}\right)$ (74.3 and $50.4 \%$, respectively). The data on hepatic weight, obtained $4 \mathrm{~h}$ after GalN/LPS injection, is shown in Figure 2B. Hepatic weight was significantly increased by GalN/LPS in the vehicle-treated control group compared with naive mice. 1,8 -Cineole $\left(400 \mathrm{mg} \mathrm{kg}^{-1}\right)$ and dexamethasone $\left(1 \mathrm{mg} \mathrm{kg}^{-1}\right)$ significantly inhibited the GalN/LPS-induced increases in hepatic weight (37.7 and $32.8 \%$, respectively).

Mice treated with GalN/LPS alone showed significant $(P<0.001)$ increases in the serum activity of ALT and AST (approx. 3.9- and 2.7-fold, respectively) com-


Figure 2 Effect of 1,8-cineole (400 $\mathrm{mg} \mathrm{kg}^{-1}$, p.o.) or dexamethasone ( $1 \mathrm{mg} \mathrm{kg}^{-1}$, s.c.) on serum TNF- $\alpha$ concentration (A) and hepatic weight (B) in mice injected with D-galactosamine/lipopolysaccharide (GalN/LPS). All pretreatments were given $1 \mathrm{~h}$ before GalN/LPS. TNF- $\alpha$ concentrations were analysed from blood serum samples collected $4 \mathrm{~h}$ after GalN/LPS. Mice were killed $4 \mathrm{~h}$ after GalN/LPS and the liver weights obtained. Mice treated with vehicle (controls, $10 \mathrm{~mL} \mathrm{~kg}^{-1} 3 \%$ Tween 80 in water, p.o.); mice treated with GalN/LPS that received vehicle, 1,8 -cineole $\left(400 \mathrm{mg} \mathrm{kg}^{-1}\right.$, p.o.) or dexamethasone $\left(1 \mathrm{mg} \mathrm{kg}^{-1}\right.$, s.c.). Data are mean \pm s.d., $\mathrm{n}=6 .{ }^{*} P<0.01$ significantly different compared with vehicle control. $\dagger P<0.01$ significantly different compared with GalN/LPS control.

pared with controls (Table 1). Pretreatment with 1,8cineole or dexamethasone caused significant $(P<0.001)$ decreases in the GalN/LPS-induced elevations of serum ALT and AST. The respective decreases in ALT and AST were 59 and $46 \%$ for 1,8 -cineole, and 72 and $51 \%$ for dexamethasone.

\section{Histological changes in the liver}

Histological sections of liver tissue taken from normal mice demonstrated well preserved architecture and disposition of hepatocytes. Vehicle-treated control mice that received GalN/LPS manifested severe liver damage characterized by diffuse inflammatory reaction 
Table 1 Effect of pretreatment with 1,8-cineole and dexamethasone on D-galactosamine/ lipopolysaccharide (GalN/LPS)-induced changes in serum alanine aminotransferase (ALT) and aspartate aminotransferase (AST) concentrations.

\begin{tabular}{|c|c|c|}
\hline Group & $\operatorname{ALT}\left(\mathbf{I U} \mathbf{L}^{-1}\right)$ & $\operatorname{AST}\left(\mathrm{IU} \mathrm{L} \mathbf{L}^{-1}\right)$ \\
\hline Vehicle control & $5.75 \pm 0.44$ & $14.48 \pm 0.99$ \\
\hline GalN/LPS control & $22.66 \pm 3.97 *$ & $39.48 \pm 4.83^{*}$ \\
\hline GalN/LPS $+1,8$-cineole (400 $\mathrm{mg} \mathrm{kg}^{-1}$, p.o.) & $9.24 \pm 0.79 \dagger$ & $21.37 \pm 1.40 \dagger$ \\
\hline GalN/LPS + dexamethasone $\left(1 \mathrm{mg} \mathrm{kg}^{-1}\right.$, s.c. $)$ & $6.40 \pm 1.18 \dagger$ & $19.30 \pm 2.48 \dagger$ \\
\hline
\end{tabular}

Data are mean \pm s.e.m., $\mathrm{n}=6$. 1,8-Cineole or dexamethasone were administered $1 \mathrm{~h}$ before administration of GalN (700 mg kg${ }^{-1}$, i.p. ) and LPS $\left(5 \mu \mathrm{g} \mathrm{kg}^{-1}\right)$. ${ }^{*} P<0.001$, significantly different compared with vehicle control. $\dagger P<0.001$, significantly different compared with GalN/LPS control.

and degenerative changes (Figure $3 \mathrm{~A}$ and $\mathrm{B}$ ). 1,8Cineole $\left(400 \mathrm{mg} \mathrm{kg}^{-1}\right)$ treatment caused only minute degenerative changes. The mice that received dexamethasone $\left(400 \mathrm{mg} \mathrm{kg}^{-1}\right)$ showed moderate to discrete microvacuolization in the hepatocytes, with only smaller areas of necrosis and haemorrhage (Figure 3C and 3D).

\section{Discussion}

This study indicates that 1,8-cineole has a protective effect against GalN/LPS-induced toxicity in mice. In this experimental model, the protection offered by $1,8-$ cineole in terms of survival of mice was associated with an inhibition of serum TNF- $\alpha$ concentrations, to a greater extent than observed with dexamethasone. The suppressive effect of 1,8-cineole is consistent with the previous report of its ability to inhibit LPS-stimulated mediator production of TNF from human blood monocytes in-vitro (Juergens et al 1998a). To our knowledge, this is the first account of the inhibitory effects of 1,8cineole on serum TNF- $\alpha$ in-vivo after GalN/LPS administration to mice. TNF is considered a pivotal mediator of endotoxic shock and therefore targeting of this mediator has often been pursued as a means of reducing mortality (Santucci et al 1996; Shindo et al 1998; Endo et al 1999). Death in endotoxic shock usually results from cardiopulmonary collapse, and specific blockade of TNF can reduce the associated morbidity and mortality (Dinarello 1991; Sekut et al 1994). Recent findings suggest that the nuclear factor KB (NF-KB) and activating protein-1 (AP-1) are the two prominent transcription factors responsible for the effects of TNF- $\alpha$. These factors mediate the induction of many proteins central to inflammatory processes and immune responses, such as cytokines, cell-adhesion molecules, growth factors, metalloproteinases that participate in the production of prostaglandins, leukotrienes and nitric oxide (Baldwin 1996). Corticosteroids such as dexamethasone can inhibit both NF-KB and AP-1 activation (Scheinmann et al 1995). In this study both 1,8-cineole (400 mg kg$\left.)^{-1}\right)$ and dexamethasone $\left(1 \mathrm{mg} \mathrm{kg}^{-1}\right)$ could completely prevent GalN/LPS-induced mortality in mice. These agents were able to suppress the elevated serum TNF- $\alpha$ concentrations associated with GalN/ LPS toxicity. From these results it could be speculated that 1,8-cineole may also possibly interfere with the functioning of nuclear factors, consequent to its inhibition of TNF- $\alpha$.

Co-administration of GalN and LPS to mice produces fulminant hepatitis with severe hepatic congestion, resulting in rapid death. Liver failure in this experimental model is known to largely involve TNF- $\alpha$ which contributes to early apoptosis followed by necrosis (Leist et al 1995; Josephs et al 2000; Nowak et al 2000). Although a larger dose of LPS alone can greatly elevate serum TNF, LPS itself does not induce hepatic congestion or rapid death. GalN has been shown to produce liver damage similar to human viral hepatitis (Decker \& Keppler 1974), and it seems to inhibit the hepatocytederived inhibitory factor thereby leading to an overproduction of TNF (Endo et al 1999). Since mice are relatively resistant to the lethal effects of LPS and because of liver-specific sensitizing action of GalN (Morikawa et al 1998), we induced liver failure in mice by co-administration of GalN and LPS. The facts that 1,8-cineole not only suppressed GalN/LPS-induced increases in liver weight and the elevation in serum transminase activity, but could also prevent the histopathologic alterations, principally the necrosis and haemorrhage to a greater extent than dexamethasone, suggest that its hepatoprotection was associated with a reduction in TNF- $\alpha$. It is possible that a higher dose of 

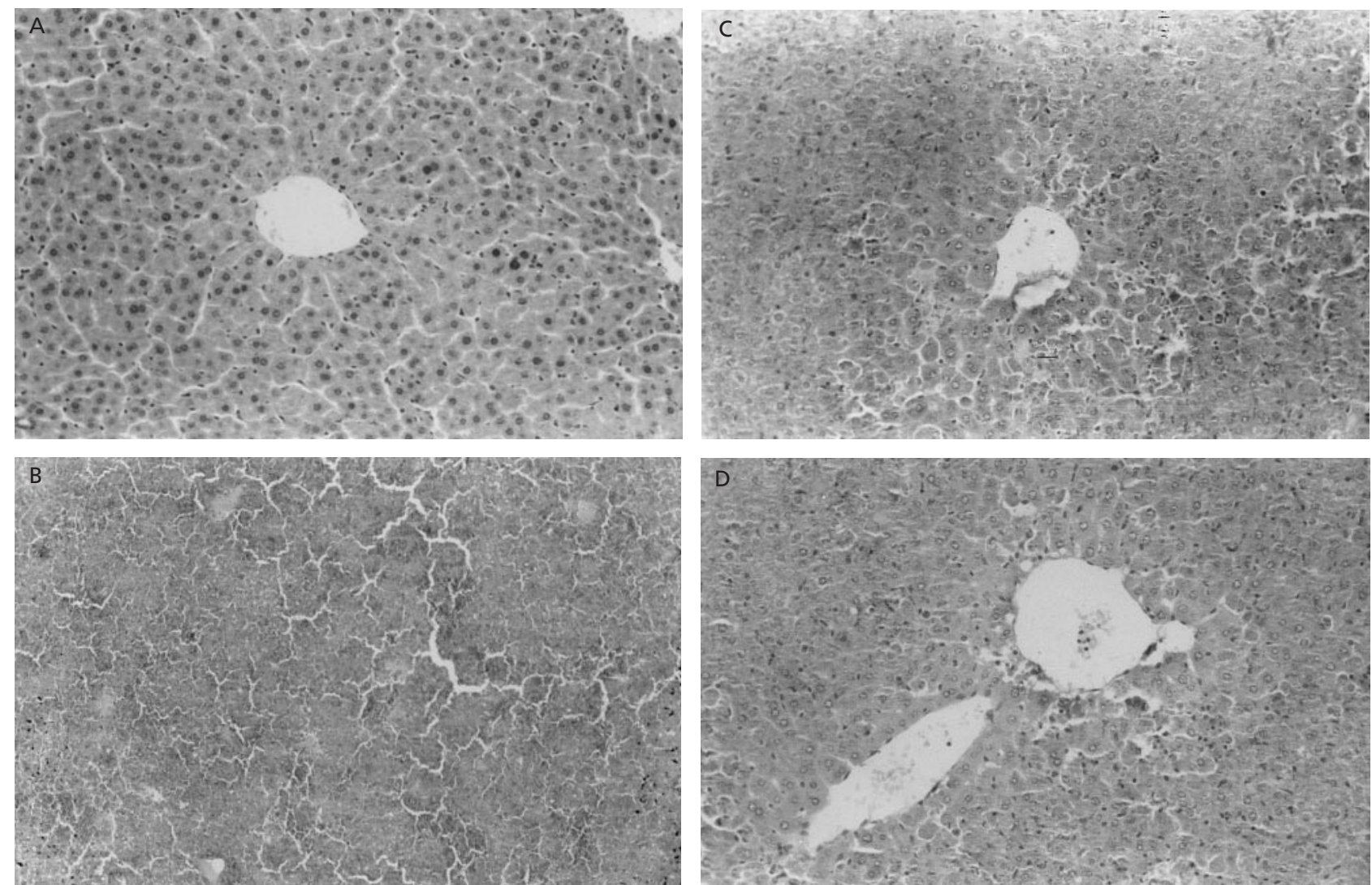

Figure 3 Photomicrograph of liver section from vehicle-treated mice showing normal architecture (A); liver section from mice that received D-galactosamine/lipopolysaccharide showing disorganized architecture, intense cellular necrosis and marked haemorrhage (B); liver section from mice treated orally with 1,8 -cineole $\left(400 \mathrm{mg} \mathrm{kg}^{-1}\right)$ showing only minute degenerative changes, less necrotic foci with no haemorrhage (C); and liver section from mice treated subcutaneously with dexamethasone $\left(1 \mathrm{mg} \mathrm{kg}^{-1}\right)$ showing smaller areas of necrosis and haemorrhage (D). All sections were stained with haematoxylin and eosin dye; magnification $\times 100$.

dexamethasone than the one used in this study (e.g. $1 \mathrm{mg} \mathrm{kg} \mathrm{kg}^{-1}$ ) might show better histological protection comparable with 1,8-cineole.

The TNF- $\alpha$ inhibitory activity of 1,8-cineole correlated well with its ability to protect mice from GalN/ LPS-induced lethality and the prevention of liver damage. A wide variety of substances have been shown to inhibit TNF induction, which includes antioxidants (Elliott et al 1991; Peristeris et al 1992; Netea et al 1995; Xie et al 1999), inhibitors of phospholipase $A_{2}$ (Spriggs et al 1990), nitric oxide synthase (Rojas et al 1993), lipoxygenase (Schade et al 1991), phosphodiesterase (Schade 1990; Fischer et al 1993; Gantner et al 1997), adenosine and its analogues (Parmely et al 1993), colchicine (Tiegs et al 1992), and melatonin (Lissoni et al 1996). Previous studies have established the anti-inflammatory potential of 1,8-cineole (Juergens et al 1998a and 1998b; Santos and Rao 2000), but its specific action as an antioxidant or as an inhibitor of phospholipase $\mathrm{A}_{2}$ remains to be assessed. From our experiments, it was found that the acute toxicity of 1,8-cineole in mice (oral LD50) was greater than $3.5 \mathrm{~g} \mathrm{~kg}^{-1}$ and therefore we consider it a relatively safe drug with possibly fewer systemic side-effects than steroids (Caduff et al 2000) or anticytokine therapy (Opal et al 1996). In conclusion, although the precise mechanism of its inhibitory effect on TNF secretion is unclear, the results of this study indicate that 1,8-cineole might offer a new therapeutic strategy to combat toxic hepatitis and other septicshock-associated pathologies.

\section{References}

Baldwin, A. S. (1996) The NF-Kappa B and I kappa B proteins: new discoveries and insights. Ann. Rev. Immunol. 14: 649-681

Caduff C., Reinhart W. H., Hartmann K., Kuhn M. (2000) Immediate hypersensitivity reactions to parenteral glucocorticoids? Analysis of 14 cases. Schweiz. Med. Wochenschr. 130: 977-983 
Decker, K., Keppler, D. (1974) Galactosamine hepatitis: key role of the nucleotide deficiency period in the pathogenesis of cell injury and cell death. Rev. Physiol. Biochem. Pharmacol. 71: 78-105

Dinarello, C. A. (1991) The proinflammatory cytokines interleukin-1 and tumour necrosis factor and treatment of the septic shock syndrome. J. Infect. Dis. 63: 1177-1184

Elliott, G. T., Welty, D., Kuo, Y. D. (1991) The D-galactosamine loaded mouse and its enhanced sensitivity to lipopolysaccharide and monophosphoryl lipid A : a role for superoxide. J. Immunother. 10: $69-74$

Endo, Y., Shibazaki, M., Yamaguchi, K. (1999) Enhancement by galactosamine of lipopolysaccharide (LPS)-induced tumor necrosis factor production and lethality: its suppression by LPS pretreatment. Br. J. Pharmacol. 128: 5-12

Fischer, W., Schudt, C., Wendel, A. (1993) Protection by phosphodiesterase inhibitors against endotoxin-induced liver injury in galactosamine-sensitized mice. Biochem. Pharmacol. 45 : 2399-2404

Gao, S., Singh, J. (1998) In vitro percutaneous absorption enhancement of a lipophilic drug tamoxifen by terpenes. J. Control. Rel. 51 : 193-199

Gantner, F., Kusters, S., Wendel, A., Hatzelmann, A., Schudt, C., Tiegs, G. (1997) Protection from T cell-mediated murine liver failure by phosphosdiesterase inhibitors. J. Pharmacol. Exp. Ther 280: $53-60$

Josephs, M. D., Bahjat, F. R., Fukuzuka, K., Ksontini, R., Solorzana, C., Edwards, C. K., Tannahill, C. L., MacKay, S. L., Copeland, E. M., Moldwer, L. L. (2000) Lipopolysaccharide and D-galactosamine-induced hepatic injury is mediated by TNF-alpha and not by Fas ligand. Am. J. Physiol. Regul. Integr. Comp. Physiol. 278 R1196-R1201

Juergens, U. R., Stober, M., Vetter, H. (1998a) Inhibition of cytokine production and arachidonic acid metabolism by eucalyptol $(1,8$ cineole) in human blood monocytes in vitro. Eur. J. Med. Res. 17 508-510

Juergens, U. R., Stober, M., Schmidt-Schilling, L., Kleuver, T., Vetter, H. (1998b) Anti-inflammatory effects of eucalyptol (1,8-cineole) in bronchial asthma: inhibition of arachidonic acid metabolism in human blood monocytes ex vivo. Eur. J. Med. Res. 17: 407-412

Laude, E. A., Morice, A. H., Grattan, T. J. (1994) The antitussive effects of menthol, camphor, and cineole in conscious guinea-pigs Pulm. Pharmacol. 7: 179-184

Leist, M., Gantner, F., Bohlinger, I., Tiegs, G., Germann, P. G., Wendel, A. (1995) Tumor necrosis factor-induced hepatocyte apoptosis precedes liver failure in experimental murine shock models. Am. J. Pathol. 146: 1220-1234

Levison, K. K., Takayama, K., Isowa, K., Okabe, K., Nagai, T. (1994) Formulation optimization of indomethacin gels containing a combination of three kinds of cyclic monoterpenes as percutaneous penetration enhancers. J. Pharm. Sci. 83: 1367-1372

Lissoni, P., Palorossi, F., Tancini, G., Barni, S., Ardizzoia, A., Brivio, F., Zubelewicz, B., Chatikhine, V. (1996) Is there a role for melatonin in the treatment of neoplastic cachexia? Eur. J. Cancer 32 A : $1340-1343$

Morikawa, A., Kato, Y., Sugiyama, T., Koide, N., Kawai, M., Fukada, M., Yoshida, T., Yokochi, T. (1998) Altered expression of constitutive and inducible type heat shock proteins in response of D-galactosamine-sensitized mice to lipopolysaccharide as an experimental endotoxic shock model. FEMS Immunol. Med. Microbiol. 21: $37-45$

Netea, M. G., Blok, W. L., Kullberg, B. J., Bemelmans, M., Vogels, M. T., Buurman, W. A., Van der Meer, J. W. (1995) Pharmacologic inhibitors of tumor necrosis factor production exert differential effects in lethal endotoxemia and in infection with live microorganisms in mice. J. Infect. Dis. 171: 393-399

Nowak, M., Gaines, G. C., Rosenberg, J., Minter, R., Bahjat, F. R., Rectenwald, J., MacKay, S. L., Edwards, C. K., Moldawer, L. L. (2000) LPS-induced liver injury in D-galactosamine-sensitized mice requires secreted TNF-alpha and the TNF-p55 receptor. Am. J. Physiol. Regul. Integr. Comp. Physiol. 278: R1202-R1209

Opal, S. M., Cross, A. S., Jhung, J. W., Young, L. D., Palardy, J. E., Parejo, N. A., Donsky, C. (1996) Potential hazards of combination immunotherapy in the treatment of experimental septic shock. $J$. Infect. Dis. 173: 1415-1421

Parmely, M. J., Zhou, W. W., Edwards, C. K., Borcherding, D. R., Silverstein, R., Morrison, D. C. (1993) Adenosine and a related carbocyclic nucleoside analog selectively inhibit tumor-necrosisfactor-alpha production and protect mice against endotoxin challenge. J. Immunol. 151: 389-396

Pattnaik, S., Subramanyam, V. R., Bapaji, M., Kole, C. R. (1997) Antibacterial and antifungal activity of aromatic constituents of essential oils. Microbios 89: 39-46

Peristeris, P., Clark, B. D., Gatti, S., Faggioni, R., Mantovani, A., Mengozzi, M., Orencole, S. F., Sironi, M., Ghezzi, P. (1992) Nacetylcysteine and glutathione as inhibitors of tumor-necrosisfactor production. Cell. Immunol. 140: 390-399

Rojas, A., Padròn, J., Caveda, L., Palacios, M., Moncada, S. (1993) Role of nitric oxide pathway in the protection against lethal endotoxemia afforded by low doses of lipopolysaccharide. Biochem. Biophys. Res. Commun. 191: 441-446

Santos, F. A., Rao, V. S. N. (1997) Mast cell involvement in the rat paw oedema response to 1,8-cineole, the main constituent of eucalyptus and rosemary oils. Eur. J. Pharmacol. 331: 253-258

Santos, F. A., Rao, V. S. N. (2000) Anti-inflammatory and antinociceptive effects of 1,8-cineole, a terpenoid oxide present in many plant essential oils. Phytother. Res. 14: 240-244

Santucci, L., Fiorucci, S., Chiorean, M., Brunori, P. M., Di-Matteo, F. M., Sidoni, A., Migliorati, G., Morelli, A. (1996) Interleukin 10 reduces lethality and hepatic injury induced by lipopolysaccharide in galactosamine-sensitized mice. Gastroenterology 111: 736-744

Schade, U. F. (1990) Pentoxifylline increases survival in murine endotoxin shock and decreases formation of tumor necrosis factor. Circ. Shock 31: 171-181

Schade, U. F., Engel, R., Jacobs, D. (1991) The role of lipoxygenases in endotoxin-induced cytokine production. Prog. Clin. Biol. Res. 367: 73-82

Scheinmann, R. I., Cogswell, P. C., Lofquist, A. K., Baldwin, A. S. (1995) Role of transcriptional activation of I kappa B alpha in mediation of immunosuppression by glucocorticoids. Science $\mathbf{2 7 0}$ : 283-286

Sekut, L., Menius, J., Brackeen, M. F., Connolly, K. M. (1994) Evaluation of the significance of elevated levels of systemic and localized tumor necrosis factor in different animal models of inflammation. J. Lab. Clin. Med. 124: 813-820

Shindo, T., Kurihara, H., Kurihara, Y., Morita, H., Yazaki, Y. (1998) Upregulation of endothelin-1 and adrenomedullin gene expression in the mouse endotoxin shock model. J. Cardiovasc. Pharmacol. 31 (Suppl. 1): S541-S544

Spriggs. D. R., Sherman, M. L., Imamura, K., Mohri, M., Rodrigues, C., Robbins, G., Kufe, D. W. (1990) Phospholipase-A activation and autoinduction of tumor-necrosis-factor gene-expression by tumor-necrosis-factor. Cancer Res. 50: 7101-7107

Tiegs, G., Wolter, M., Wandel, A. (1989) Tumor necrosis factor is a terminal mediator in D-galactosamine/endotoxin-induced hepatitis in mice. Biochem. Pharmacol. 38: 627-631 
Tiegs, G., Freudenberg, M. A., Galanos, C., Wendel, A. (1992) Colchicine prevents tumor necrosis factor-induced toxicity in vivo. Infect. Immunol. 60: 1941-1950

Williams, A. C., Barry, B. W. (1991) Terpenes and the lipid-proteinpartitioning theory of skin penetration enhancement. Pharm. Res. 8: $17-24$
Xie, X. L., Ding, M., Dong, Z. G., Chen, F., Ye, J. P., Wang, S. W., Leonard, S. S., Casranova, V., Vallyathan, V. (1999) Antioxidant properties of aspirin: characterization of the ability of aspirin to inhibit silica-induced lipid peroxidation, DNA damage, NF-Kappa B activation, and TNF-alpha production. Mol. Cell. Biochem. 199: 93-102 